\title{
Ground-Water Depletion Across the Nation
}

Ground-water use has many societal benefits. It is the source of drinking water for about half the nation and nearly all of the rural population, and it provides over 50 billion gallons per day in support of the Nation's agricultural economy. Ground-water depletion, a term often defined as long-term water-level declines caused by sustained ground-water pumping, is a key issue associated with ground-water use. Many areas of the United States are experiencing ground-water depletion.

$\mathrm{A}$ $\mathrm{n}$ aquifer can be compared to a bank account, and ground water occurring in an aquifer is analogous to the money in the account. Hydrologists refer to this type of accounting as a water budget. Ground water can be recharged (deposited) by infiltration from precipitation, surface water, or applied irrigation water; it can be kept in storage (saved); and it can be discharged naturally to streams, springs, or seeps, or transpired by plants (withdrawn). In a ground-water system prior to development, the system is in longterm equilibrium - discharge is equal to recharge, and the volume of water in storage remains relatively constant. Ground-water levels fluctuate in time over a relatively small, natural range. Once pumping begins, however, this equilibrium is changed and groundwater levels decline. Just as a bank account must be balanced, withdrawals from an aquifer by pumping must be balanced by some combination of increased recharge, decreased discharge, and removal from storage (or depletion). An inventory of ground-water levels in wells reflects the volume of water stored (or occurring) in the aquifer, and is analogous to a financial statement.

The volume of ground water in storage is decreasing in many areas of the United States in response to pumping.
Ground-water depletion is primarily caused by sustained ground-water pumping. Some of the negative effects of ground-water depletion include increased pumping costs, deterioration of water quality, reduction of water in streams and lakes, or land subsidence. Such effects, while variable, happen to some degree with any ground-water use. As with other natural resources, society must weigh the benefits against the consequences of such use. In order to provide the scientific information needed for informed decisions, these effects must be observed over time to determine their impact.

\section{What are some effects of ground- water depletion?}

If intensive pumping from an aquifer continues, then adverse effects may occur.

Water-well problems Declining groundwater levels have three main effects on water wells. First, as the depth to water increases, the water must be lifted higher to reach the land surface. As the lift distance increases, so does the energy required to drive the pump. Thus, power costs increase as ground-water levels decline. Depending on the use of the water and the energy costs, it may no longer be economically feasible to use water for a given purpose. Second, ground-water levels may decline below the bottom of existing pumps, necessitating the expense of lowering the pump, deepening the well, or drilling a deeper replacement well. Third, the yield of the well may decline below usable rates.

Ground-water budgets before and after development of the Gulf Coastal Plain aquifer system (all flows in cubic feet per second). The large withdrawals from the aquifers have been balanced by increases in recharge to the aquifer system and decreases in storage and discharge from the aquifer system (modified from Williamson and Grubb, 2001).

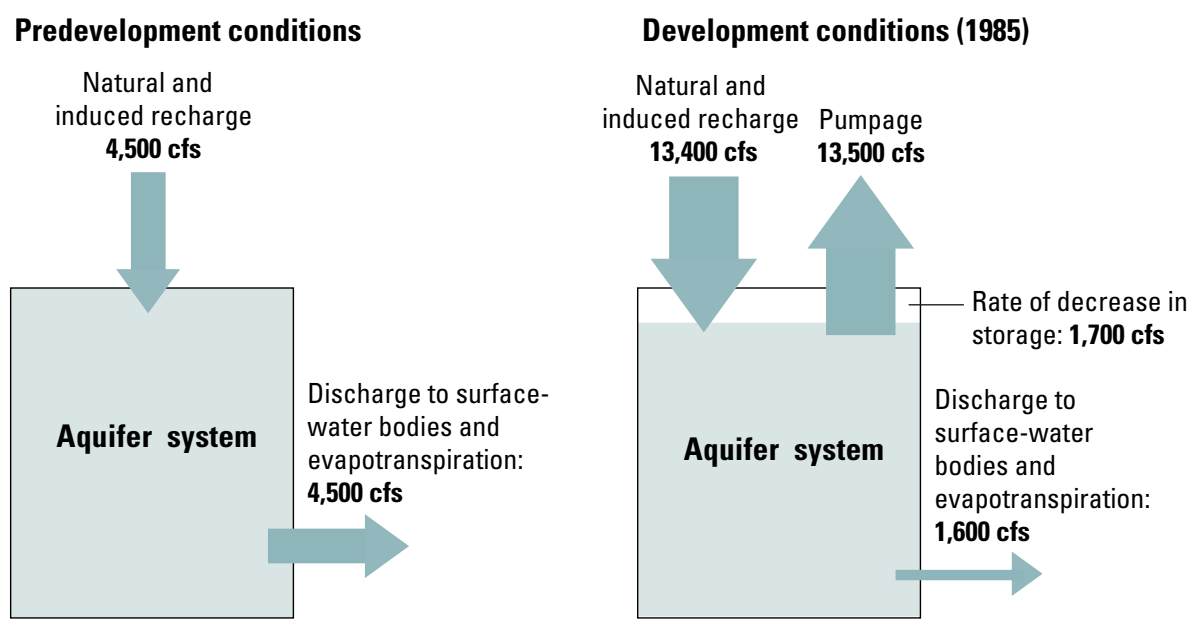




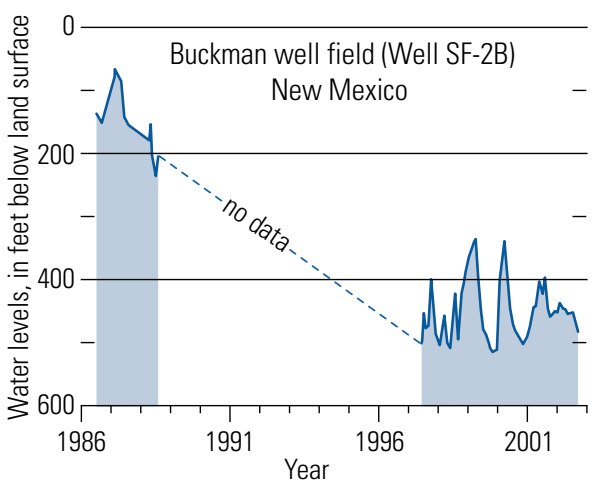

A hydrograph showing ground-water-level declines in the Buckman well field, which supplies water for Santa Fe, New Mexico. No measurements were made between August 1988 and June 1997, during which time water levels declined nearly 300 feet, emphasizing the importance of continual monitoring. Long-term data that document the evolving response of aquifers to ground-water development are particularly important for calibrating ground-water-flow models used to forecast future conditions.

Reduced surface-water flows In most areas, the surface- and ground-water systems are intimately linked. Groundwater pumping can alter how water moves between an aquifer and a stream, lake, or wetland by either intercepting ground-water flow that discharges into the surface-water body under natural conditions, or by increasing the rate of water movement from the surfacewater body into an aquifer. In either case, the net result is a reduction of flow to surface water, though the full effect may take many years to develop.

A related effect of ground-water pumping is the lowering of groundwater levels below the depth that streamside or wetland vegetation needs to survive. The overall effect is a loss of riparian vegetation and wildlife habitat.

Subsidence Land subsidence is "a gradual settling or sudden sinking of the Earth's surface owing to subsurface movement of earth materials." Though several different earth processes can cause subsidence, more than 80 percent of the subsidence in the United States is related to the withdrawal of ground water (Galloway and others, 1999).

\section{Deterioration of water quality}

Coastal aquifers tend to have wedgeshaped zones of saltwater underlying the potable freshwater. Under natural conditions the boundary between the freshwater and saltwater tends to be relatively stable, but pumping can cause saltwater to migrate inland, resulting in saltwater contamination of the water supply. Inland aquifers can experience similar problems where withdrawal of good-quality water from the upper parts of inland aquifers can allow underlying saline water to move upward and degrade water quality. Additionally, where ground water is pumped from an aquifer, surface water of poor or differing quality may be drawn into the aquifer. This can degrade the water quality of the aquifer directly or mobilize naturally occurring contaminants in the aquifer.

\section{Where does ground-water depletion occur in the United States?}

Ground-water depletion has been a concern in the Southwest and High Plains for many years, but increased demands on our ground-water resources have overstressed aquifers in many areas of the Nation, not just in arid regions. In addition, ground-water depletion occurs at scales ranging from a single well to aquifer systems underlying
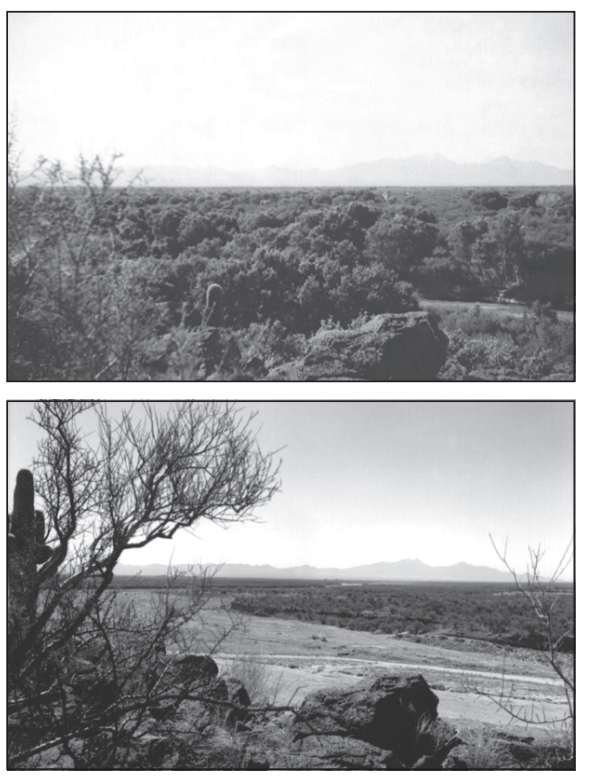

A 1942 photograph (top) of a reach of the Santa Cruz River south of Tucson, Arizona, shows stands of mesquite and cottonwood trees along the river. A photograph (bottom) of the same site in 1989 shows that the riparian trees have largely disappeared, as a result of lowered ground-water levels.

Photos: Robert H. Webb, USGS several states. The extents of the resulting effects depend on several factors including pumpage and natural discharge rates, physical properties of the aquifer, and natural and human-induced recharge rates. Some examples from east to west across the Nation are given below.

Atlantic Coastal Plain In Nassau and Suffolk Counties, Long Island, New York, water pumped for domestic supply is used and sent to a wastewater-treatment plant and then discharged into the surrounding saltwater bodies. As a result of these actions, the water table has been lowered, the base flow of streams has been reduced or eliminated, the length of perennial streams has been decreased, and saline ground water has moved inland.

Many other locations on the Atlantic coast are experiencing similar effects related to ground-water depletion. Surface-water flows have been reduced due to ground-water development in the Ipswich River basin, Massachusetts. Saltwater intrusion is occurring in coastal counties in New Jersey; Hilton Head Island, South Carolina; Brunswick and Savannah, Georgia; and Jacksonville and Miami, Florida (Barlow, 2003).

West-central Florida Ground-water development in the Tampa-St. Petersburg area has led to saltwater intrusion and subsidence in the form of sinkhole development and concern about surface-water depletion from lakes in the area. In order to reduce its dependence on ground water, Tampa has constructed a desalination plant to treat seawater for municipal supply.

Gulf Coastal Plain Several areas in the Gulf Coastal Plain are experiencing effects related to ground-water depletion:

Ground-water pumping by Baton Rouge, Louisiana, increased more than tenfold between the 1930s and 1970 , resulting in ground-water-level declines of approximately 200 feet. Baton Rouge is underlain by a series of aquifers, and pumping has shifted among them with time. The large water-level declines have resulted in saltwater encroaching from the Gulf 


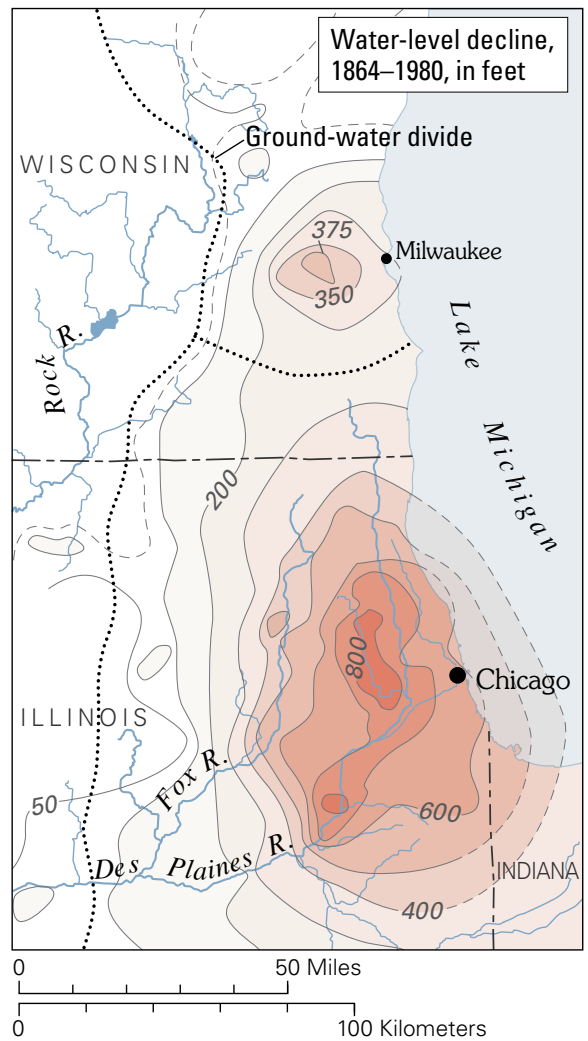

Decline in ground-water levels in the sandstone aquifer, Chicago and Milwaukee areas, 1864-1980 (Alley and others, 1999).

of Mexico into several of the aquifers (Taylor and Alley, 2001).

In the Houston, Texas, area, extensive ground-water pumping to support economic and population growth has caused water-level declines of approximately 400 feet, resulting in extensive land-surface subsidence of up to 10 feet. Among other issues, subsidence is responsible for increased susceptibility to flooding and the permanent inundation of some areas.

Continued pumping since the 1920s by many industrial and municipal users from the underlying Sparta aquifer have caused significant waterlevel declines in Arkansas, Louisiana, Mississippi, and Tennessee. Such declines have caused concerns about the Sparta's sustainability resulting in the aquifer being declared "critical" in Arkansas. The Memphis, Tennessee, and West Memphis, Arkansas, area is one of the largest metropolitan areas in the world that relies exclusively on ground water for municipal supply. These large withdrawals have caused regional water-level declines of up to 70 feet, and have resulted in interstate concerns over continued and increased pumping in the Memphis area.

High Plains The High Plains aquifer (which includes the Ogallala aquifer) underlies parts of eight States and has been intensively developed for irrigation. Since predevelopment, water levels have declined more than 100 feet in some areas and the saturated thickness has been reduced by more than half in others. Water levels are recovering in some areas due to management by State and local agencies, improved irrigation efficiency, low crop prices, and agricultural programs (McGuire and others, 2003).

Chicago-Milwaukee area Since the first documented water well was completed in the Chicago area in 1864 , ground water has been the sole source of drinking water for about 8.2 million people in the Great Lakes watershed. This long-term pumping has lowered ground-water levels by as much as 900 feet in the sandstone aquifer underlying the Chicago area and eastern Wisconsin. Concern over how such pumping affected surface water in the Great Lakes region led to the reduction of ground-water withdrawals in much of the area. Water levels are recovering in some areas, however, declines continue in others (Grannemann and others, 2000).
Pacific Northwest Ground-water development of the Columbia River Basalt aquifer of Washington and Oregon for irrigation, public-supply, and industrial uses has caused waterlevel declines of more than 100 feet in several areas; management efforts to reduce withdrawals have reversed some of the declines. The Snake River Plain aquifer in Idaho provides water for extensive irrigation as well as much of the flow of the Snake River through springs. Since 1950, water levels and spring discharge have decreased due to intensive use of ground water for agriculture (Burns, 1997).

Desert Southwest Increased groundwater pumping to support population growth in south-central Arizona (including the Tucson and Phoenix areas) has resulted in water-level declines of between 300 and 500 feet in much of the area. Land subsidence was first noticed in the 1940s and subsequently as much as 12.5 feet of subsidence has been measured. Additionally, lowering of the water table has resulted in the loss of streamside vegetation as documented by historical photographs.

In 1999, Las Vegas, Nevada, was the fastest growing municipal area in the United States. In places, ground-water levels have declined 300 feet since the

Locations in the basins of southern California, Nevada, Utah, Arizona, and New Mexico where substantial ground-water level declines have been measured. In some areas, water levels have recovered in response to reduction in pumping and increased recharge efforts (Leake and others, 2000).

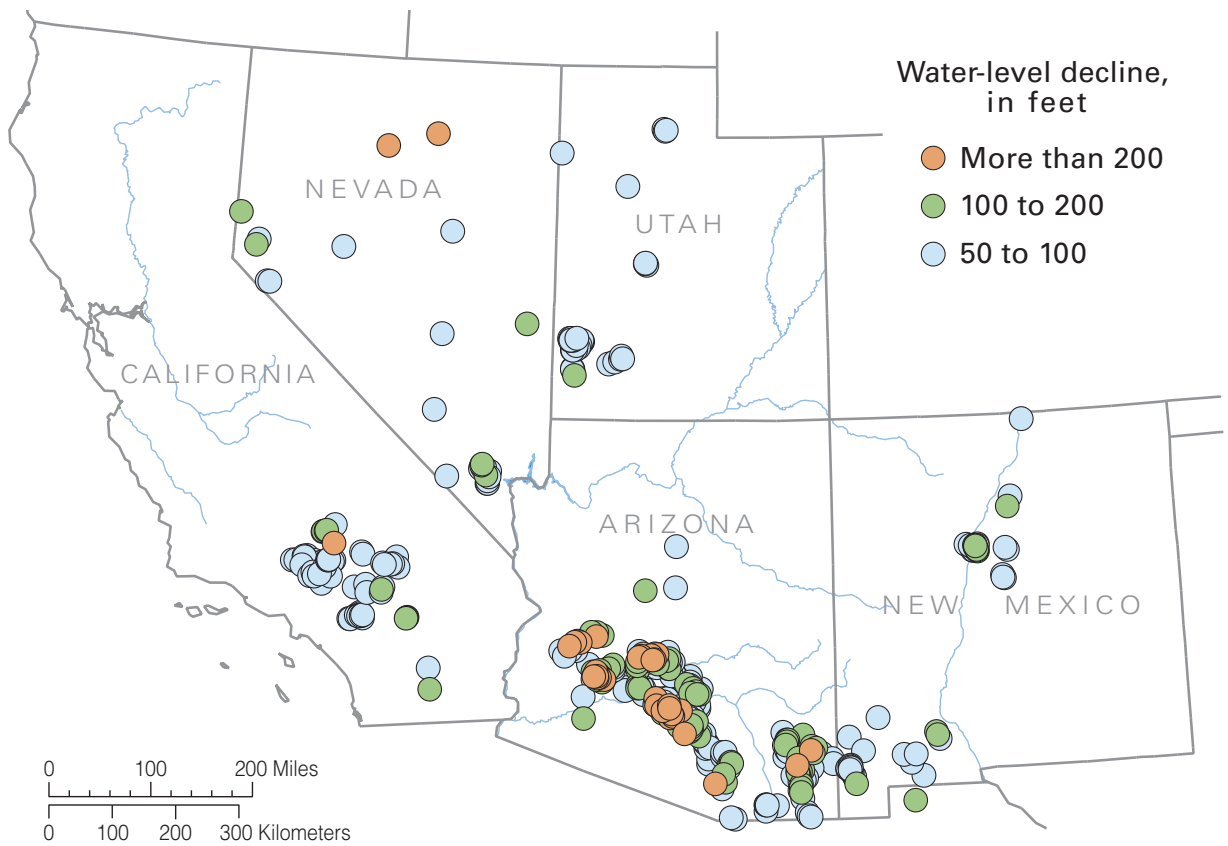




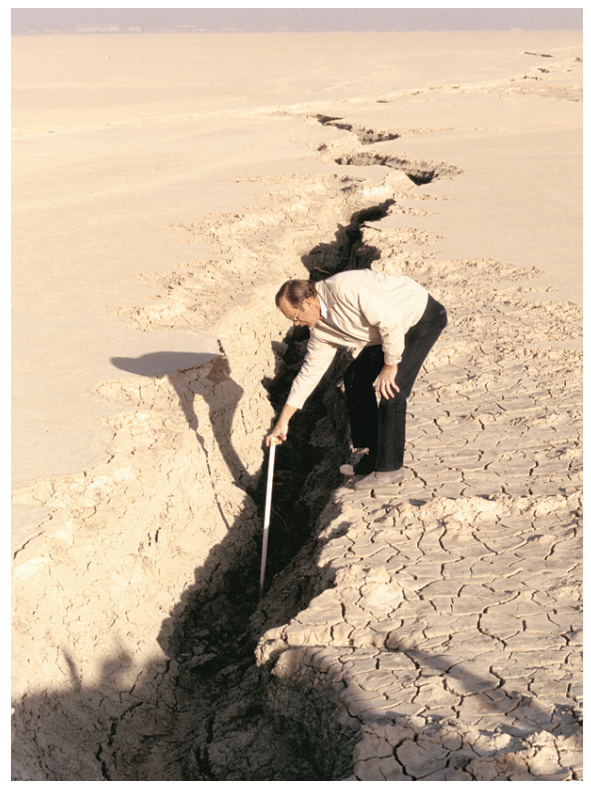

This earth fissure formed on Rogers Lake at Edwards Air Force Base, California, in January 1991, and forced the closure of one of the space shuttle's alternative runways. The fissure has been attributed to land subsidence related to ground-water pumping in the Antelope Valley area (Galloway and others, 2003).

first flowing artesian well was drilled in 1907. These water-level declines have resulted in as much as 6 feet of subsidence since 1935, as well as having caused springs to dry up and artesian wells to stop flowing (Pavelko and others, 1999).

In Antelope Valley, on the western edge of the Mojave Desert in southern California, water-level declines have exceeded 300 feet in some areas since the early 1900s. As a result, measured land subsidence exceeded 6 feet locally between 1930-92. The land surface is continuing to subside, resulting in damage to roads, buildings, and other structures (Galloway and others, 2003).

\section{What information do we need to monitor the Nation's ground- water depletion and its effects?}

About 140 million residents (about 50 percent of the population) in all 50 States depend on ground water for their direct needs. Ground water provides about 40 percent of the Nation's public-water supply and much of the water used for irrigation. This reliance on ground water necessitates long-term monitoring of ground-water levels to track ground-water depletion. Though water-level monitoring takes place for many aquifer systems within individual States, coordinated waterlevel monitoring generally has not been done for aquifers that cross State boundaries (the High Plains aquifer is an exception). No comprehensive national ground-water-level network exists with uniform coverage of major aquifers, climate zones, or land uses.

Long-term ground-water-level data from individual wells provide the information needed to monitor ground-water depletion locally. Periodic assessments of changes in ground-water storage could be made by measuring more wells over larger areas at 5- to 10-year intervals. Such changes could be documented for major aquifers and then compiled into regional and national assessments. A major task at the beginning of such an assessment would be the analysis of ground-water withdrawals and changes in storage that occurred during the 20th century (U.S. Geological Survey, 2002).

In order to preserve and optimize the use of our critical ground-water resources, science can provide the information necessary to make informed choices on issues that have long-term environmental and ecological effects. For many aquifers in the United States, the basic data needed for such assessments are not available, and hence our knowledge of the water budget for them is limited. In about 1950, in Albuquerque, New Mexico, several supply wells were pumped dry, leading C.V. Theis, one of the major scientists in the field of hydrogeology, to comment, "What happened was that the city got a notice from its bank that its account was overdrawn and when it complained that no one could have foreseen this, only said in effect that it had no bookkeeping system" (Theis, 1953).

-J.R. Bartolino and W.L. Cunningham

\section{REFERENCES}

Alley, W.M., Reilly, T.E., and Franke, O.L., 1999, Sustainability of ground-water resources: U.S. Geological Survey Circular 1186, 79 p

Barlow, P.M., 2003, Ground water in freshwatersaltwater environments of the Atlantic coast: U.S. Geological Survey Circular 1262.

Burns, A.W., 1997, Sidebar 2-2-Ground-water resources in the western United States - Sustainability and trends, in Western Water Policy Review Council, Water for the West-The challenge for the next century, Public Review Draft, October 1997, p. 2.10-2.16.

Galloway, D.L., Jones, D.R., and Ingebritsen, S.E., eds., 1999, Land subsidence in the United States: U.S. Geological Survey Circular 1182, 177 p

Galloway, D.L., Alley, W.M., Barlow, P.M., Reilly, T.E., and Tucci, Patrick, 2003, Evolving issues and practices in managing ground-water resources: Case studies on the role of science: U.S. Geological Survey Circular $1247,73 \mathrm{p}$.

Grannemann, N.G., Hunt, R.J., Nicholas, J.R., Reilly, T.E., and Winter, T.C., 2000, The importance of ground water in the Great Lakes region: U.S. Geological Survey Water-Resources Investigations Report 00-4008, 14 p.
H. John Heinz III Center for Science, Economics and the Environment, 2002, The State of the Nation's ecosystems--Measuring the Lands, waters, and living resources of the United States: Cambridge, UK, Cambridge University Press, 151 p.

Leake, S.A., Konieczki, A.D., and Rees, J.A.H., 2000, Desert basins of the Southwest: U.S. Geological Survey Fact Sheet 086-00, 4 p.

McGuire, V.L., Johnson, M.R., Schieffer, R.L., Stanton, J.S., Sebree, S.K., and Verstraeten, I.M., 2003, Water in storage and approaches to ground-water management, High Plains Aquifer, 2000: U.S. Geological Survey Circular 1243, 51 p.

Pavelko, M.T., Wood, D.B., and Laczniak, R.J., 1999 Las Vegas, Nevada, in Galloway, D.L., Jones, D.R., and Ingebritsen, S.E., eds., Land subsidence in the United States: U.S. Geological Survey Circular 1182 , p. 49-64.

Taylor, C.J., and Alley, W.M., 2001, Ground-waterlevel monitoring and the importance of long-term water-level data: U.S. Geological Survey Circular $1217,68 \mathrm{p}$

Theis, C.V., 1953, Outline of ground-water conditions at Albuquerque-Talk given to Chamber of
Commerce, in Theis, C.V., and others, 1991, Short papers on water resources in New Mexico, 1937-57: U.S. Geological Survey Open-File Report 91-81, $77 \mathrm{p}$.

U.S. Geological Survey, 2002, Concepts for national assessment of water availability and use: U.S. Geological Survey Circular 1223, $34 \mathrm{p}$.

Williamson, A.K., and Grubb, H.F., 2001, Groundwater flow in the Gulf Coast aquifer systems, south-central United States: U.S. Geological Survey Professional Paper 1416-F, p. F1-F173, plates 1 and 7 in pocket.

\begin{tabular}{|c|}
\hline For more information \\
on ground-water-resource issues, please contact: \\
Chief, Office of Ground Water \\
U.S. Geological Survey \\
411 National Center \\
12201 Sunrise Valley Drive \\
Reston, VA 20192 \\
(703) 648-5001 \\
http://water.usgs.gov/ogw
\end{tabular}

